\title{
筋骨格モデルを用いた順動カ学シミュレーションによる 垂直跳び動作時の筋活動分析*
}

\author{
福住 敦 ${ }^{* 1}$, 竹原 昭一郎 ${ }^{* 2}$, 長谷 和徳 ${ }^{* 2}$, 吉村 卓也 ${ }^{* 2}$

\section{Muscle Activity Analysis in Vertical Jump by Direct Dynamics Simulation with Musculo-Skeletal Model}

\author{
Atsushi FUKUZUMI ${ }^{*}$, Shoichiro TAKEHARA, Kazunori HASE and Takuya YOSHIMURA \\ ${ }^{* 1}$ Tokyo Metropolitan University. Dept. of Mechanical Engineering \\ 1-1, Minami-Osawa, Hachioji, Tokyo, 192-0397 Japan
}

\begin{abstract}
In this study, the vertical jump is examined as a basic study of jump. And we examine the influence of each muscle of the human body in vertical jump. The human body is modeled as four rigid bodies and analyzed in detail by using the model that includes muscles of the leg. In this research, the mechanism of jump is discussed by using numerical model to which the concept of multibody dynamics and biomechanics is adapted. We performed the experiment of jump and observe the feature behavior of vertical jump. Experimental results show that the angle of each body becomes vertical for ground and the change of the foot angle is small. Then we perform the numerical simulation referring to this experimental data. In order to reduce the amount of calculation, we calculate muscular activity level by correlating it with fewer parameters. We discuss which muscles are necessary for vertical jump. It is found that vasti exerts the biggest power and gluteus maximus has the highest state of normalized muscle activity.
\end{abstract}

Key Words : Biomechanics, Multibody Dynamics, Muscle, Musculoskeletal System, Vertical Jump

\section{1. 緒言}

現在，スポーツは趣味として行う人からそれを職業として行う人まで多くの人々にとって身近なものである. スポーツは走行や歩行，跳躍などの様々な動作を含んでいる．跳躍動作を例に考えてみると，陸上の分野では走 り高跳びや走り幅跳び，球技の分野ではバスケットボールやバレーボールにおいて重要な運動の一つであり，跳 躍動作においては跳躍高を向上させることが課題である. そのため, 跳躍運動のメカニズムを工学的に解明する ことは興味深いことであり，それはバスケットボールなどの競技のみではなく，ロボットへの応用の可能性があ る. 本研究では, 垂直跳びを対象とし, 跳躍運動の基礎的な知見を得ることを目的とする. 跳躍運動として垂直 跳びを対象とする先行研究としては, 筋肉と人の運動生成の関係に着目したものや, 垂直跳びの最高到達点の高 さと跳躍時の初期姿勢の関係を調べたものがある(1) (3). また, 跳躍ロボットに関する研究では, 二関節筋に着目 し, 跳躍運動におけるその重要性について述べているものがある ${ }^{(4)(5)}$. しかし, 文献 1,2 では筋肉の活動状態をそ れぞれの筋肉ごとに求めるため計算量が大きくなってしまうといった問題もある. そのため, 本研究では筋肉の 活動状態を他のパラメータに依存させることで，筋肉の活動状態の計算量を小さくすることを試み，マルチボデ イ・ダイナミクスとバイオメカニクスの概念を用いて跳躍運動のメカニズムについて検討する. その時, 人体を 4 剛体リンクとしてモデル化し, さらに筋肉を付加したモデルを用いて解析を行う. 人体のモデル化に関しては, マルチボディ・ダイナミクス理論の一つである拡大法を用いて定式化を行う(6) (8). また，筋肉は先行研究で用い られている筋モデルを用いる(9). そして，本モデルを用いて垂直跳びの跳躍高を向上させる最適な運動パターン

* 原稿受付 2010 年 11 月 12 日

*1 首都大学東京大学院 理工学研究科 機械工学専攻（广192-0397 東京都八王子市南大沢 1-1）

*2 正員, 首都大学東京 理工学研究科

E-mail: stakeha@tmu.ac.jp 
について検討し，各筋肉が跳躍高に与える影響を定量的に評価することを目的とする.

\section{2. モデリング及び定式化}

\section{$2 \cdot 1$ モデリング}

本研究では, 脚部の筋力配分のため, 図 1 に示寸ように, 脚部に注目して人体のモデリングを行う。このモデ ルは，矢状面における 2 次元モデルとし，人体を足・下腿・大腿・上体の四つの部位に分け，剛体として扱う. このモデルにおいて剛体 1 を足（Foot），剛体 2 を下腿（Shank），剛体 3 を大腿（Thigh），剛体 4 を上肢，頭部を 含む上体（Head-Arm-Trunk：HAT）とする．また各剛体間は関節位置においてピン結合により接続されるものと する.この時，第 1 関節を足関節，第 2 関節を膝関節，第 3 関節を股関節とする．なお，各剛体の重心位置に重 力，関節位置において各剛体に関節トルクを外力として与える.

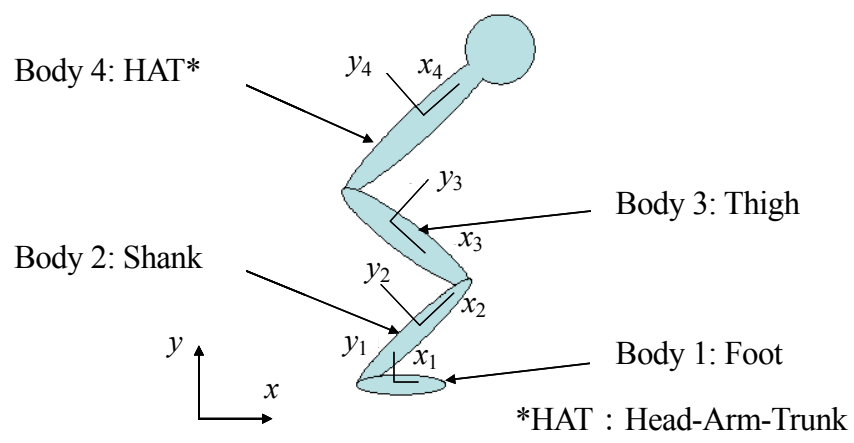

Fig.1 Rigid link model for human jumping

\section{$2 \cdot 2$ 運動方程式}

本モデルは，マルチボディ・ダイナミクスの手法の一つである拡大法 ${ }^{(6)}{ }^{(8)}$ により運動方程式を求める， $x_{i}, y_{i}$ を剛体 $i$ の重心の座標, $\theta_{i}$ を各剛体の回転角度とすると, $\mathrm{n}$ 個からなる剛体系の一般化座標は以下のようになる.

$$
\mathbf{q}=\left[\begin{array}{lllllll}
x_{1} & y_{1} & \theta_{1} & \ldots & \theta_{i} & \ldots & \theta_{n}
\end{array}\right]^{T} \quad(i=1 \sim n)
$$

$\mathbf{M}$ を質量マトリクス，Q を外力ベクトルとすると，仮想仕事の原理より，

$$
[\mathbf{M} \ddot{\mathbf{q}}-\mathbf{Q}]^{T} \delta \mathbf{q}=0
$$

となる.

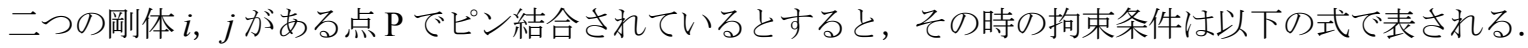

$$
\boldsymbol{\Phi}^{(i, j)}(\mathbf{q}, t)=\left[\mathbf{r}_{i}+\mathbf{A}_{i} \overline{\mathbf{u}}_{i}^{P}-\mathbf{r}_{j}-\mathbf{A}_{j} \overline{\mathbf{u}}_{j}^{P}\right]
$$

$\mathbf{r}_{i, j}$ は剛体 $i, j$ の重心の位置ベクトルであり,$\overline{\mathbf{u}}_{i, j}^{P}$ は剛体 $i, j$ の重心に設定された局所座標上の点 $\mathrm{P}$ の位置ベクトル, $\mathbf{A}_{i j}$ は局所座標系から全体座標系への座標変換マトリクスである.

ラグランジュの未定乗数を拘束力の記述として用いると，

$$
[\mathbf{M} \ddot{\mathbf{q}}-\mathbf{Q}]^{T} \delta \mathbf{q}+\lambda^{T} \boldsymbol{\Phi}_{\mathbf{q}} \delta \mathbf{q}=0
$$

となる.ここで下付き添え字は関数をその添え字の変数で偏微分することを表す. 
式（4）より

$$
\mathbf{M} \ddot{\mathbf{q}}+\boldsymbol{\Phi}_{\mathbf{q}}^{T} \lambda-\mathbf{Q}=0
$$

となる.さらに拘束条件式を時間で二回微分した加速度方程式は

$$
\boldsymbol{\Phi}_{\mathbf{q}} \ddot{\mathbf{q}}=\gamma, \quad \gamma \equiv-\frac{d \boldsymbol{\Phi}_{\mathbf{q}}}{d t} \dot{\mathbf{q}}-\frac{d \boldsymbol{\Phi}_{t}}{d t}=-\left(\boldsymbol{\Phi}_{\mathbf{q}} \dot{\mathbf{q}}\right)_{\mathbf{q}} \dot{\mathbf{q}}-\left(2 \boldsymbol{\Phi}_{\mathbf{q}}\right)_{t}-\boldsymbol{\Phi}_{t t}
$$

となる．式（5）と式（6）を連立させることで以下のような微分代数方程式が得られる.

$$
\left[\begin{array}{cc}
\mathbf{M} & \boldsymbol{\Phi}_{\mathbf{q}}^{T} \\
\boldsymbol{\Phi}_{\mathbf{q}} & \mathbf{0}
\end{array}\right]\left[\begin{array}{l}
\ddot{\mathbf{q}} \\
\lambda
\end{array}\right]=\left[\begin{array}{l}
\mathbf{Q} \\
\gamma
\end{array}\right]
$$

式（7）を用いて拘束力 $\boldsymbol{\lambda}$ ，加速度 $\ddot{\mathbf{q}}$ を求め，数值積分を行うことによって運動解析を行う.

\section{$2 \cdot 3$ 筋骨格モデル}

\section{$2 \cdot 3 \cdot 1$ 筋モデル}

人体の各筋はその機能, 及び付着位置より, いくつかの筋群としてまとめることができる. 本研究では, 垂直 跳び動作を発生させるのに必要な筋骨格系のモデルを図 2 のように定める(9). なお，筋の幾何学的位置は関節の 屈曲の状態によって変化するが，ここでは簡略化のため, 筋のモーメントアームは関節角度によらず一定とし, 滑車モデルとして表現する.

剛体リンクモデルにおける関節モーメント $T_{i}^{F}$ はこれらの筋により生じる筋張力の合力として次式により表さ れる.

$$
T_{i}^{F}=\sum_{m} \operatorname{arm}_{i m} F_{m}
$$

ここで, $a_{i m}$ は第 $i$ 関節における $m$ 番目の筋のモーメントアーム, $F_{m}$ は $m$ 番目の筋の筋張力であり, 各筋は質 量を考慮しない力発生要素とする. したがって筋の収縮に伴う各リンクの重心位置や慣性モーメントの変化はな いものとする. なお，各リンクにおける力のつりあい式を考えた場合，厳密には各筋の張力により各筋の付着位 置や関節点位置に拘束力が生じるが, これらの力は各リンクに内力として打ち消されるため, 各リンクの運動に は直接関与しないと考えることができる.

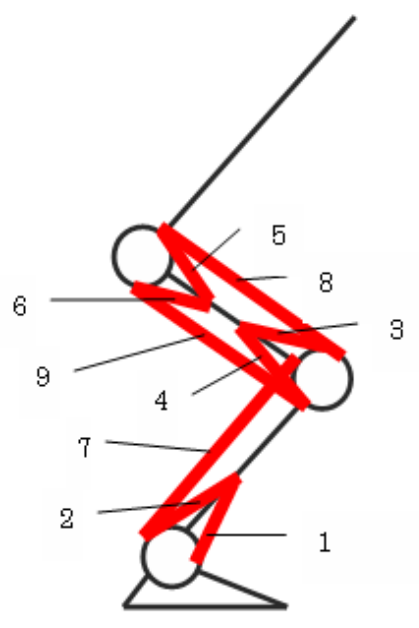

1: Tibialis anterior(TA)

2 : Soleus(SOL)

3 : Vasti(VAS)

4 : Short head of biceps femoris (SHBF)

5 : Ilipsoas(ILI)

6 : Gluteus maximus(GM)

7 : Gastrocnemius(GAS)

8 : Rectus femoris(RF)

9 : Hamstrings(HAM)

Fig.2 Musculoskeletal model 
次に, 各筋が発揮する筋張力を求めるため, 筋の力学特性を考慮して, 次式を用いる(10).

$$
F_{m}=F_{m}^{M A X} \operatorname{lf}\left(\xi_{m}\right) \operatorname{vf}\left(\eta_{m}, \xi_{m}\right) s_{m}
$$

ここで $F_{m}$ は筋張力, $F_{m}{ }^{M A X}$ は最大筋収縮力, If $\left(\xi_{m}\right)$ は筋の長さ一力関係式, vf $\left(\xi_{m}, \eta_{m}\right)$ は速度一力関係式, $\xi_{m}$ は筋長を筋の自然長で正規化した值， $\eta_{m}$ は筋の収縮速度を最大収縮速度で正規化した值， $s_{\mathrm{m}}$ は正規化筋活動状態 $\left(0 \leqq s_{m} \leqq 1\right)$ である.ここで， $s_{\mathrm{m}}$ は，筋の活動状態を正規化したものであり，発揮させたい関節トルク相当量を 最大関節卜ルクで正規化した值を基に計算している.この時, 筋の数は関節の自由度の数に対して冗長に存在し, 直接的に個々の筋活動を決定することができないため，筇活動状態は以下の手順で決定した ${ }^{(9)}$.

(1) 前脛骨筋のように一つの関節トルク相当量に対応する筋肉が一つしかない場合, 関節卜ルク相当量を筋 活動状態 $s_{\mathrm{m}}$ と定める.

(2) 二関節筋と一関節筋が同期的に働く場合，二関節筋の筋出力を先に定める．二関節筋がまたがる二つの 関節の関節トルク相当量の中で，主動関係にある関節トルク相当量とは興奮結合し，拮抗関係にある関 節トルク相当量とは抑制結合により結合する.このときの結合の強さは生理断面積の比例関係に応じて 定め，これにより二関節筋の筋活動状態を定める.

(3) 最後に一関節筋の筋出力を求める. 一関節筋はそれぞれに対応寸る関節トルク相当量からの出力により 基本的に制御され，さらに協調関係にある二関節筋の出力分をこれより差し引く．さらに拮抗関係にあ る一関節筋の影響分も加え, 筋活動状態を定める.

\section{$2 \cdot 3 \cdot 2$ 人体パラメータ}

この節では，シミュレーションに用いるモデルのパラメータの設定を行う. パラメータとしては，身体寸法， 慣性パラメータ, 筋骨格パラメータ, 関節受動要素に関わるパラメータがある. 身体の各寸法, および節の質量, 重心位置，慣性モーメントなどの慣性パラメータに関しては文献 ${ }^{(1)}$ を参照して，表 1 のように定めた。この值は 身長 $1.75 \mathrm{~m}$, 体重 $62 \mathrm{~kg}$ の成人男子を想定して算出したデータである. なお，重心位置は地面との接地点に対す る近位点からの距離とした. さらに, 筋の生理断面積, 筋長などの筋骨格系のパラメータは文献 ${ }^{(12)(13)}$ を参照して 定め, 各関節受動要素関数は文献 ${ }^{(14)(15)}$ を参照し, 以下の式のように定義した.

$$
\operatorname{passive}_{i}\left(\Delta \theta_{i}, \Delta \dot{\theta}_{i}\right)=-k_{i 1}^{J} \exp \left\{k_{i 2}^{J}\left(\Delta \theta_{i}-\overline{\Delta \theta_{i}}+k_{i 3}^{J}\right)\right\}+k_{i 4}^{J} \exp \left\{-k_{i 5}^{J}\left(k_{i 6}^{J}+\Delta \theta_{i}-\overline{\Delta \theta_{i}}\right)\right\}-c_{i}^{J} \Delta \dot{\theta}_{i}
$$

ここで $k_{i l}{ }^{J} \sim k_{i b}{ }^{J}$ は係数であり, $\Delta \bar{\theta}_{i}$ は自然立位状態における関節角度を表わす基準関節角度, $c_{i}^{J}$ は粘性係数であ る. この式の第 1 項と第 2 項が弾性受動特性を表わしており, これらの係数の值を表 2 に示寸. なお, 文献值で は実現不可能な運動を生成する可能性があったため, それを回避するため係数を新たに定めた.

\section{3. 跳躍実験}

\section{$3 \cdot 1$ 実験概要}

垂直跳びの基本的な動作の確認を目的として，垂直跳びの動作を撮影する実験を行った．この時，計測点は中 足点, 踝, 膝, 股, 腰の計 5 点とし, 中足点の初期位置を原点とした. 本検討では被験者を 3 人とした.

表 3 に各被験者の身長, 体重, 各部位の節長を示す. 胴体に関しては各被験者の身長の比から求めた ${ }^{(11)}$.

\section{$3 \cdot 2$ 実験結果}

図 3 5 に実験結果を示寸. 図 3 は各被験者の各接地時間（0，25，50，75，100\%）での跳躍姿勢を示す.ここ で，接地時間とは，動作開始を 0 , 終了の時間を 100 とした場合の百分率であり，本論文での動作開始は身体の 重心が下降から上昇に転じる瞬間とし，終了を中足点が地面から離れる瞬間とした．なお，この時の各被験者の 動作開始から跳躍までに要した時間は 0.23 0.29 s であった．図 4 に被験者の各部位（足，下腿，大腿，胴体）の 水平面角度（反時計が正）の時刻歴を示す. 
Table 1 Inertia parameters of the body segments

\begin{tabular}{c|cccc}
\hline & $\begin{array}{c}\text { Mass } \\
{[\mathrm{kg}]}\end{array}$ & $\begin{array}{c}\text { Moment of inertia } \\
{\left[\mathrm{kgm}^{2}\right]}\end{array}$ & $\begin{array}{c}\text { Center of mass } \\
{[\mathrm{m}]}\end{array}$ & $\begin{array}{c}\text { Length } \\
{[\mathrm{m}]}\end{array}$ \\
\hline Foot & 1.800 & 0.015 & 0.969 & 0.194 \\
Shank & 5.770 & 0.092 & 0.237 & 0.418 \\
Thigh & 12.400 & 0.224 & 0.236 & 0.417 \\
HAT & 42.040 & 2.479 & 0.307 & 0.490 \\
\hline
\end{tabular}

Table 2 Coefficients of Joint passive function

\begin{tabular}{c|cccccccc}
\hline & $k_{i 1}^{J}$ & $k_{i 2}^{J}$ & $k_{i 3}^{J}$ & $k_{i 4}^{J}$ & $k_{i 5}^{J}$ & $k_{i 6}^{J}$ & $c_{i}^{J}$ & $\overline{\Delta \theta}_{i}[\mathrm{deg}]$ \\
\hline Ankle & 20.00 & 20.00 & -1.25 & 20.00 & 20.00 & 0.40 & 1.00 & -70 \\
Knee & 3.10 & 5.90 & -1.92 & 10.50 & 21.80 & 0.12 & 1.72 & 0 \\
Hip point & 2.60 & 3.00 & -0.10 & 8.70 & 1.30 & 1.92 & 1.09 & 0 \\
\hline
\end{tabular}

図 4 より，各被験者間で初期姿勢において各部位の水平面角度に違いがあることが見てとれる．被験者 1 は足 と大腿，下腿と胴体の初期角度がほぼ同じ角度である. 一方，被験者 $2 ， 3$ の結果では足と大腿の初期角度の違い は少ないが，下腿と胴体の初期角度は約 20 度の違いがあり，胴体の角度の方が大きいことがわかる.また初期角 度の範囲は足が約 120 140 度，下腿が約 40 50 度，大腿が約 130 140 度，胴体が約 45 70 度であり，足と胴体の 初期角度は被験者間の違いが大きいことがわかる.また動作中の角度の変化を見ると, 各被験者とも, 足の角度 変化が最も小さく, 約 10 度程度変化しており, 下腿, 大腿, 胴体では 20 40 度の変化がある. また, 各被験者 の動作中の各部位の角度変化を見ると，初期姿勢に違いは見られるものの，跳躍時（接地時間 100\%）に向かっ て，各部位の角度は90 度に近づいていることがわかる.

次に，跳躍動作中の関節角度の変化に着目する．図 5 は関節角度の時刻歴を示す。この時，関節角度は以下の 式のように求めた。 なお， $\Delta \theta_{i}$ は第 $i$ 関節の関節角度， $\theta_{i}$ は剛体 $i$ の水平面角度である.

$$
\Delta \theta_{i}=\theta_{i+1}-\theta_{i} \quad(i=1 \sim 3)
$$

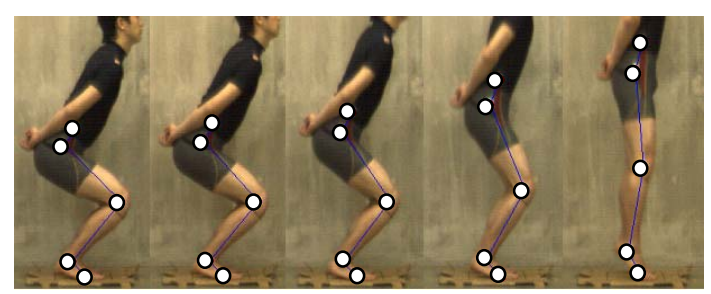

(1) Subject 1

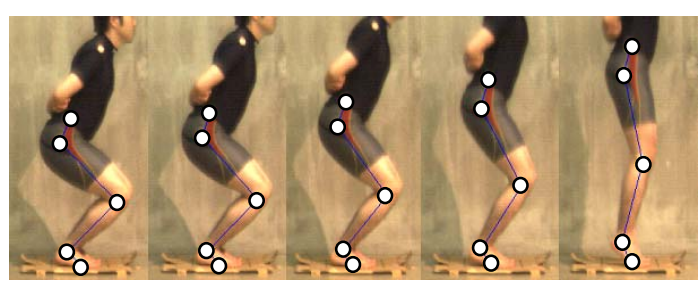

(3) Subject 3

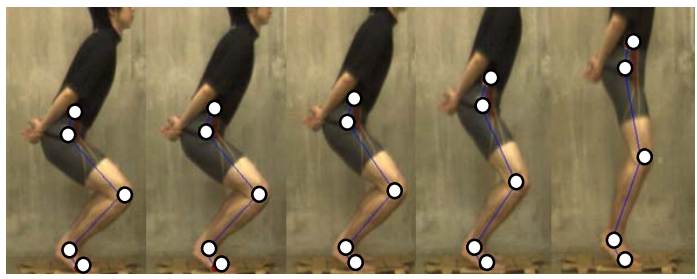

(2) Subject 2

Fig.3 Jump posture (Experiment) 
Table 3 Subject parameter

\begin{tabular}{l|cccccc}
\hline & $\begin{array}{c}\text { Height } \\
{[\mathrm{m}]}\end{array}$ & $\begin{array}{c}\text { Weight } \\
{[\mathrm{kg}]}\end{array}$ & Foot & Shank & Thigh & HAT \\
\hline Subject 1 & 1.75 & 62 & 0.12 & 0.40 & 0.46 & 0.50 \\
Subject 2 & 1.68 & 58 & 0.10 & 0.39 & 0.42 & 0.48 \\
Subject 3 & 1.65 & 64 & 0.09 & 0.36 & 0.42 & 0.47 \\
\hline
\end{tabular}

図 5 から垂直跳びの動作において，身体の各関節は伸びようとする動作を行っている．つまり，身体は跳躍時 に関節角度を 0 度に近づけるような制御を行っていると見ることができる。このことから，発揮させたい関節卜 ルクの目安となる量である関節トルク相当量を式（12）で定義する.

$$
T_{i}{ }^{\prime}=-K_{i}\left(\Delta \theta_{i}-\Theta_{i}\right)(i=1 \sim 3)
$$

ここで, $T_{i}^{\prime}$ は第 $i$ 関節にかかる関節トルク相当量, $K_{i}$ は第 $i$ 関節の比例ゲイン, $\Theta_{i}$ は第 $i$ 関節の最終跳躍姿勢で ある。なお，最終跳躍姿勢は上記の理由よりすべて 0 度とする.

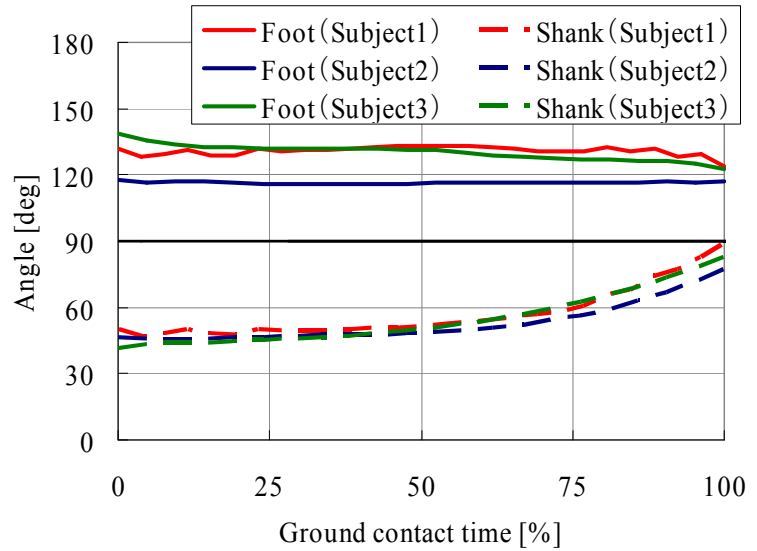

(1) Foot and Shank

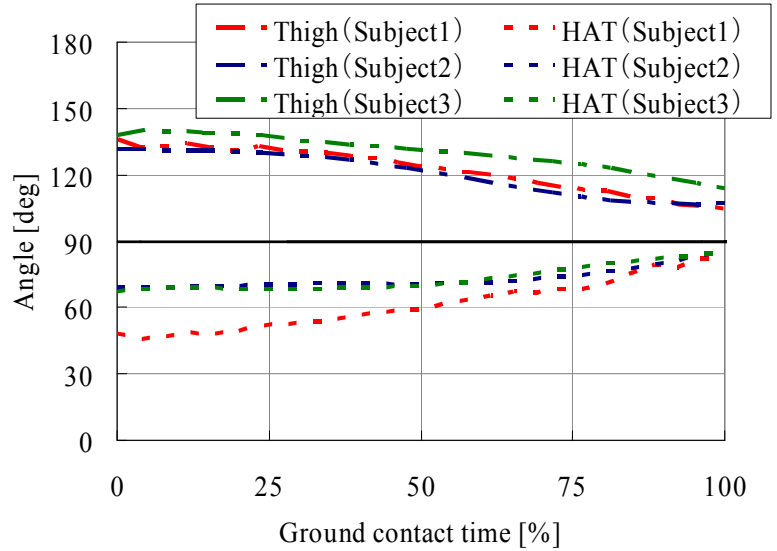

(2) Thigh and HAT

Fig.4 Time history of angle of each body

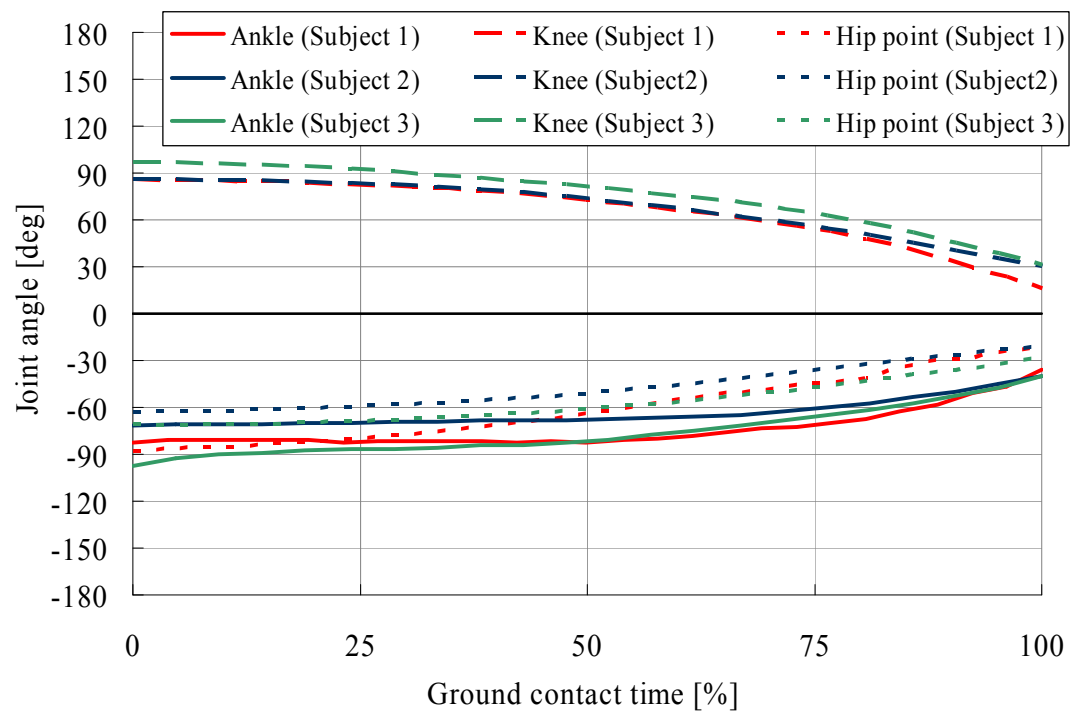

Fig.5 Time history of joint angle 


\section{4. 数值シミュレーション}

\section{$4 \cdot 1$ シミュレーション方法}

ここでは, 得られた運動方程式から人体モデルの数值シミュレーションを行う. 数值積分法は 4 次のルンゲク ッタ法を用いる.この時の時間の刻み幅は $0.001 \mathrm{~s}$ とした. 本検討では，動作開始（身体の重心が下降から上昇に 転じる瞬間）から跳躍する瞬間までの解析を行う．跳躍の定義は床反力が $0 \mathrm{~N}$ になる瞬間に跳躍したものとし， 跳躍高はその跳躍時の全剛体の重心の鉛直方向の速度を用いて式（13）のように求める. 床反力は式（7）よりべ クトル $\lambda$ の鉛直方向成分になる.

$$
\begin{aligned}
& \text { height }=\left(\text { height }_{f}+\frac{\left\{v_{C M}\left(t_{f}\right)\right\}^{2}}{2 g}\right)-\text { height }_{0} \\
& v_{C M}=\left(m_{1} v_{1}+m_{2} v_{2}+m_{3} v_{3}+m_{4} v_{4}\right) / m
\end{aligned}
$$

ここで height は跳躍高, height $t_{0}$ は立位状態での全剛体の重心の高さ, height 位, $m$ は全剛体の質量, $v_{\mathrm{CM}}$ は全剛体の重心の鉛直方向の速度, $m_{i}, v_{i}$ は剛体 $i$ の重心の質量, 鉛直方向の速度, $t_{f}$ は跳躍時の時間である.

また，各剛体の初期角度，初期角速度は実験から得られた值を基にして設定する.

\section{$4 \cdot 2$ 評価方法}

式（12）において，ゲイン $K_{i}$ の值を評価に十分な範囲で変化させてシミュレーションを行う。この際，ゲイン の值を離散化し，範囲内にある全てのゲインの組み合わせに対してシミュレーションを行う。そして以下の条件

(C1: Condition 1) において跳躍高が最大になるゲイン $K_{i}$ の組み合わせを探し出し，その時の最高到達点，跳躍 姿勢を求める. 今回行った探索範囲を表 4 に示す.

$$
s_{m}(t) \leq 1\left(m=1 \sim 9, t=0 \sim t_{f}\right)
$$

Table 4 Search range of gains

\begin{tabular}{c|cc}
\hline & Search range & Search interval \\
\hline$K_{1}$ & $70 \sim 120$ & 1 \\
$K_{2}$ & $150 \sim 190$ & 1 \\
$K_{3}$ & $15 \sim 20$ & 1 \\
\hline
\end{tabular}

\section{$4 \cdot 3$ シミュレーション結果}

式（7）を用いて身長 $1.75 \mathrm{~m}$, 体重 $62 \mathrm{~kg}$ の人体に対する垂直跳び動作の解析を行った結果を図 6 9 に示す. 図 6 はゲインと跳躍高の関係を示し， $\mathrm{z}$ 軸を跳躍高，x，y軸をゲインとしている．また，条件 (C1) の可否を赤青 の二色で示し, 青い部分は条件 $(\mathrm{C} 1)$ を満たした部分，赤い部分は条件 $(\mathrm{C} 1)$ を満たしていない部分である.よ って，青い部分の中で最も跳躍高が高いゲインの組み合わせが探索範囲内において最適なゲインの組み合わせと 言える. 図 7，8，9 は跳躍姿勢, 各筋の運動中に発揮する筋張力, 各筋の正規化筋活動状態 $s_{m}$ の結果を示寸.こ れらの図の横軸は接地時間とし，動作の開始時刻を 0, 跳躍するまでの時間を 100 とした場合の百分率で表して いる.

図 7 より，前章の実験結果に比べ，十分に胴体を持ち上げることができず，胴体の角度は最終跳躍姿勢として 設定した 0 度から離れ，胴体が前傾してしまっていることが確認できる. 図 8 より垂直跳びの動作において, 発 揮する力が大きいのは広筋（VAS）, ヒラメ筋（SOL），大臀筋（GM）であることがわかる. しかし，図 9 より筋 の活動状態を表す正規化筋活動状態の最大值の大きさで比較すると，大臀筋の正規化筋活動状態が一番大きく， 次いでヒラメ筋，広筋となり，大臀筋の強度が垂直跳びにおいて影響が大きいことがわかる．この時の跳躍高に 注目すると, 最大跳躍高の值は $0.310 \mathrm{~m}$ であり, 動作開始から跳躍までに要した時間は $0.198 \mathrm{~s}$ であった. 
次にゲインと跳躍高の関係に注目する．式（12）で足関節，膝関節，股関節のゲイン $K_{i}$ はそれぞれ独立に設定 したが，図 6 より，跳躍高はゲイン $K_{1}, K_{2}$ に対して帯状に高くなる範囲が見られ，ゲイン $K_{1}, K_{2}$ に比例して大

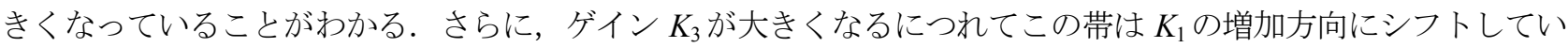
く．このことより，跳躍高に対しゲインのそれぞれの值には相関があることがわかる．また，条件を満たす部分 はこの帯上に存在するが，股関節のゲイン $K_{3}$ が 18 を超えると足関節，膝関節のゲインによらず，正規化筋活動 状態が 1 を超えてしまい，条件を満たすことができないことが確認できる．この時， $s_{m}$ が 1 を超えてしまう筋を 調べると，大臀筋であることがわかった，つまり，大臂筋はゲイン $K_{3} に$ 対寸る寄与率が高く，十分に力を発揮し ていないため，胴体を持ち上げることができず，跳踓時の姿勢が実験結果に比べ前傾姿勢になってしまったもの と考えられる.

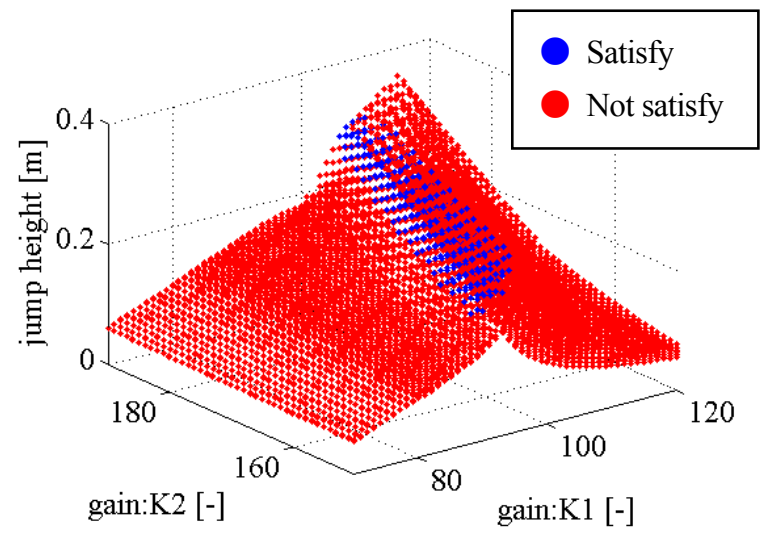

(1) $x: \operatorname{gain} K_{1}, y: \operatorname{gain} K_{2}$

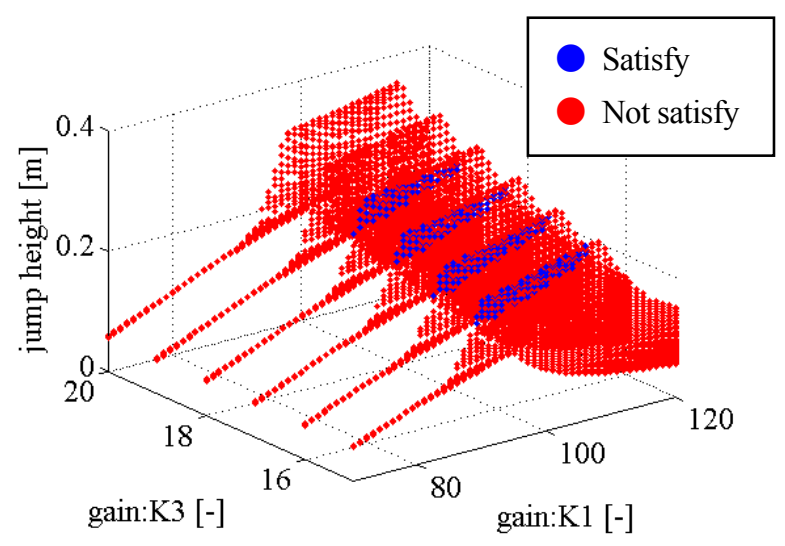

(2) $x:$ gain $K_{1}, y:$ gain $K_{3}$

Fig.6 Relation of Jump height and gains (C1)

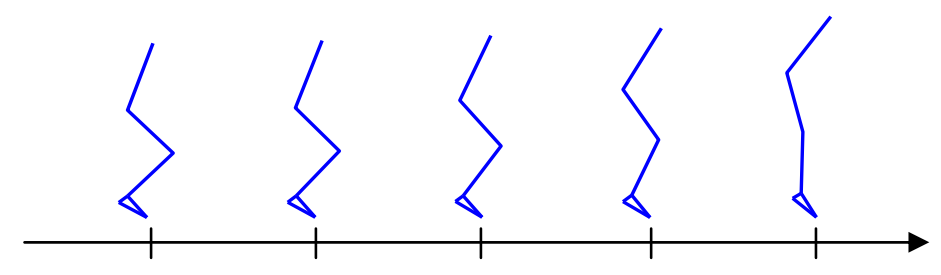

Ground contact time [\%]

Fig.7 Jump posture (simulation:C1)

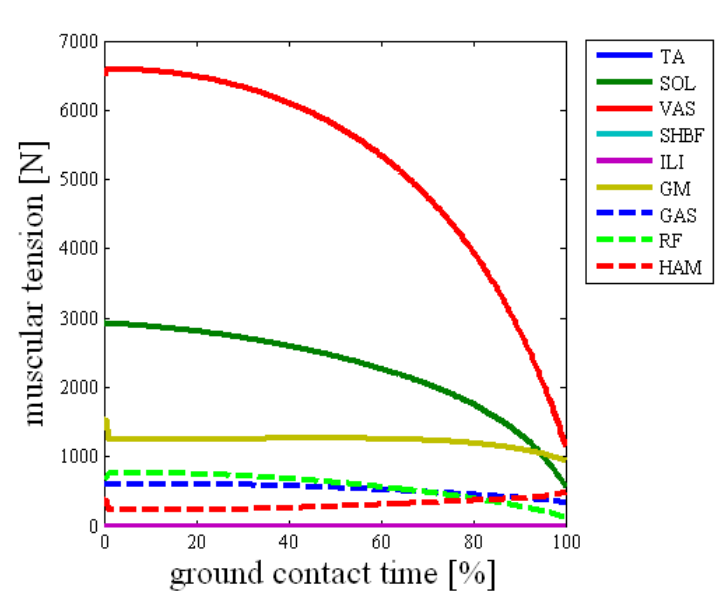

Fig.8 Muscular tension (C1)

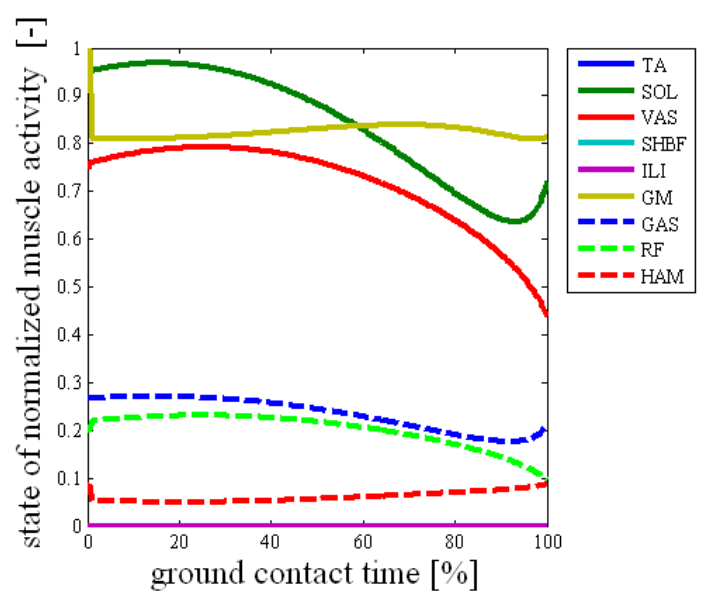

Fig.9 State of normalized muscle activity (C1) 


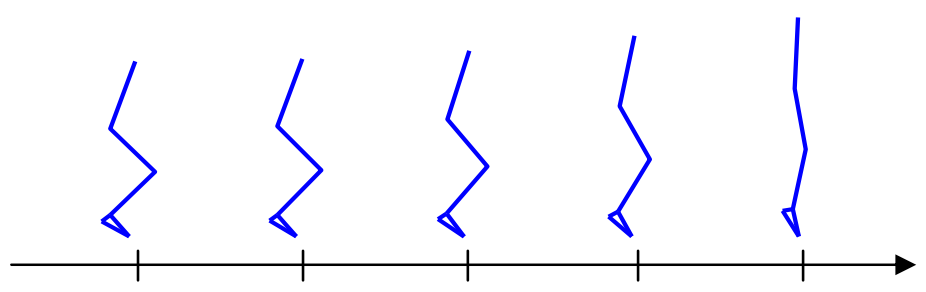

Ground contact time [\%]

Fig.10 Jump posture (simulation:C2)

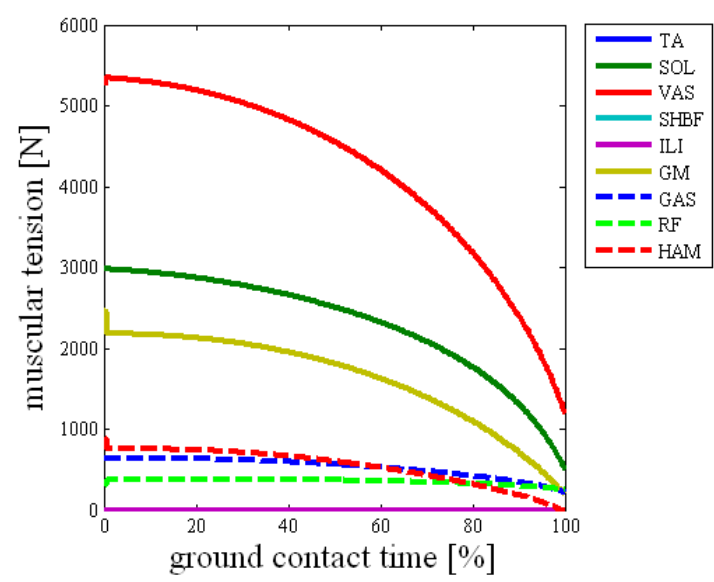

Fig.11 Muscular tension (C2)

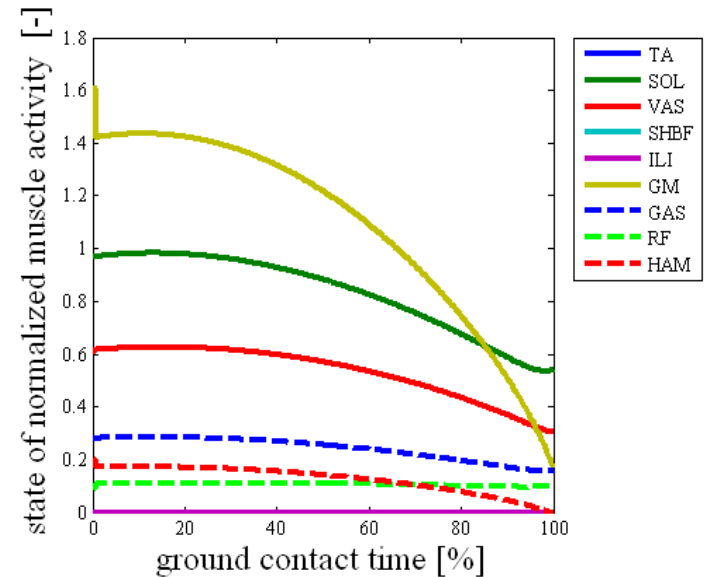

Fig.12 State of normalized muscle activity (C2)

次に，より実験結果に近い跳躍姿勢を実現するために，大臂筋の $s_{m}$ のみ， 1 以下という条件を設定せず，大臀 筋が十分に力を発揮できる場合においても検討を行った。 そのため以下の条件 (C2: Condition 2) で再度シミュレ ーションを行う。

$$
s_{m}(t) \leq 1 \quad\left(m=1 \sim 9, t=0 \sim t_{f}, \text { where } m \neq 6\right)
$$

なお，上記の条件は式（9）の正規化筋活動状態の定義から外れるものであるが，式（9）における最大筋収縮力 などの基本的なパラメータは文献 12,13 にあるような歩行運動モデルのものを採用していることを考慮し, 大臀 筋の拘束条件を外した条件でシミュレーションを行った。式（15）の条件（C2）において，シミュレーションを 行った結果を図 10 12 に示寸．図 10 から，筋力による関節トルクによりモデルの各部位が垂直方向に伸び上が っている様子が確認できる．この結果は実験結果で得られた動作の傾向と近いことから，本シミュレーションは 基本的な垂直跳び動作を表現できていると考えることができる．次に筋の発揮した筋張力に着目すると，図 11 から，広筋が一番力を発揮しており，次いでヒラメ筋，大慰筋となっていることがわかる．また，この時の筋の 活動レベルを調べると, 図 12 より大臂筋が一番高く, その次にヒラメ筋, 広筋となっている. この現象は前述の シミュレーションで得られた傾向と等しい. ここで筋張力と活動状態の大きさが逆転している理由として考えら れるのが，筋の強度，言い換えれば，各筋の生理断面積の大きさによる違いが考えられる，その他に，式（8）か らわかるように筋張力は筋の長さ, 収縮速度に依存するため, 各筋にとって力を出しやすい姿勢状態であるかと いう違いが考えられる.この時の跳躍高は $0.407 \mathrm{~m}$ あり,動作開始から跳躍までに要した時間は $0.246 \mathrm{~s}$ であった. 文献 ${ }^{(16)}$ より一般に垂直跳びの跳躍高の平均は $0.37 \pm 0.03 \mathrm{~m}$ 程度であり，一般に比べ高い結果が得られた.

以上の結果より，跳躍動作について，大臀筋，広筋などの寄与度が相対的に大きいことが示された．これらの 筋は股関節，膝関節運動のみに関与寸る一関節筋である。一方，跳躍ロボットの研究からは大腿直筋，八ムス卜 リングスのような二関節筋の機能の重要性 ${ }^{(4)(5)}$ も指摘されているが, 二関節筋跳躍ロボットでは主に上体の動きが 考慮されていない場合が多く，力の大きさよりも操作性のような力や運動のし易さについての議論が主に行われ ている. これに対して, 本研究では, 上体の動きも考慮し, 操作性に関する議論ではなく, 筋力などの力の大き 
さのみを議論の対象としている. これらの相違が一関節筋，二関節筋の評価の違いになっているものと考えられ る. 二関節筋などの筋機能の力学的解釈の問題は興味深い課題であり, 今後さらなる検討を要する.

\section{5. 結 言}

本論文では跳躍動作のメカニズムを検討するため，基本的な跳踓動作である垂直跳びに注目した．また，垂直 跳び動作の跳躍高を最大にする筇の使い方を求めることが可能なモデルの構築を行った．このモデルを用い数值 シミュレーションを行うことで垂直跳び動作における筋力および筋の活動状態の推定を行った. これにより各筋 の影響を定量的な評価を行った。

本研究で得られた知見を以下に示す.

・ 人体を 4 剛体リンクモデルとして跳躍に特化したモデリングを行い, 筋モデルを付加し, 筋力によるモ デルの駆動を実現した.

・垂直跳び動作の特徵的な挙動を調べるために跳躍実験を行い, 跳躍動作中に関節角度が関節を伸展させ る方向に変化することがわかった.

・ 数值シミュレーションを行うことで垂直跳び動作において最も大きな力を発揮している筋肉は広筋であ り，筋の活動状態が最も高いのは大慰筋であることが推定された。このことから垂直跳び動作において 一関節筋の出力, 活動状態が数值的に大きいことが推定できた.

\section{文献}

(1) Pandy, M.G.., Zajac, F.E., Sim, E., and Levine, W.S., "An Optimal Control Model for Maximum-Height Human Jumping", Journal of Biomechanics, Vol. 23, No. 12 (1990), pp. 1185-1198.

(2) Spagele, T., Kistner, A., and Gollhofer, A., "Modelling, simulation and optimization of a human vertical jump", Journal of Biomechanics, Vol. 32 (1999), pp. 521-530.

(3) Selbie, W.S., and Caldwell, G.E., "A Simulation Study of Vertical Jumping from Different Starting Postures", Journal of Biomechanics, Vol. 29, No. 9 (1996), pp.1137-1146.

(4) 鳥海清司, 大島 徹, 藤川智彦, 熊本水頼, 百生 登, “ヒトの腓腹筋である二関節筋の装備が跳躍運動に及ぼす影 響”, 日本機械学会論文集 C 編, Vol. 69, No. 688 (2003), pp. 123-128.

(5) 大島 徹, 鳥海清司, 藤川智彦, 百生 登, “足関節と膝関節の二関節筋による協調機能を用いた跳躍メカニズム”, 日本機械学会論文集 C 編, Vol. 71, No. 712 (2005), pp. 176-182.

（6）日本機械学科編，マルチボディ・ダイナミクス (2) 一数值解析と実際一 (2007), コロナ社.

(7) Shabana, A.A., Computational Dynamics, Second Edition (2001), John Wiley \& Sons, Inc.

(8) Shabana, A.A., Dynamics of Multibody System, Third Edition (2005), Cambridge University Press.

(9) Hase, K., and Yamazaki, N., "Computational evolution of human bipedal walking by a neuro-musculo-skeletal model", Artificial Life and Robotics, Vol. 3 (1999), pp. 133-138.

(10) Hatze, H., “A Myocybernetic Control Model of Skeletal Muscle”, Biological Cybernetics, Vol. 25 (1977), pp. 103-119.

(11) Winter, D.A., Biomechanics and Motor Control of Human Movement, Third Edition (2005), John Wiley \& Sons, Inc.

(12) 山崎信寿, “2 足歩行の総合解析モデルとシミュレーション”, バイオメカニズム, Vol. 3 (1975), pp. 261-269.

(13) Winters, J.M., and Woo, S.L., Multiple Muscle System (1990), Springer Verlag.

(14) Audu, M.L., "Optimal Control Modeling of Lower Extremity Musculoskeletal Motion", Ph.D.Dissertation, Case Western Reserve University, Cleveland (1985).

(15) Davy, D.T., and Audu, M.L., "A Dynamic Optimization Technique for Predicting Muscle Force in The Swing Phase of Gait", Journal of Biomechanics, Vol. 20, No. 2 (1987), pp. 187-201.

(16) Anderson, F.C., and Pandy, M.G., "A Dynamic Optimization Solution for Vertical Jumping in Three Dimensions”, Computer Methods in Biomechanics and Biomechanical Engineering, Vol. 2 (1999), pp. 201-231. 